\title{
Based on the Fan Economy, Explore the Impact of Private Brand Avatar and Advertising Attitudes on Consumer Repurchase Intentions
}

\author{
${ }^{*} \mathrm{Li}-\mathrm{Yu}$ Tseng ${ }^{1}$, Min-jing $\mathrm{Mai}^{2}$, Hao-Nan $\mathrm{Xu}^{3}$, Sheng-Ao Dong ${ }^{4}$ \\ 1,3-4 Business School, Nanfang College of Sun Yat-Sen University \\ ${ }^{2}$ New Oriental Education \& Technology Group \\ "Corresponding author. Email: zengly@nfu.edu.cn
}

\begin{abstract}
Marketing decision analysis, operation performance, and business model innovation are increasingly important elements of fan economic theory which means that the fans will support their favorite celebrity or brand with money, and much attention has been paid to the impacts of avatars. This study explores the structural relationship of private-brand avatar consistency, private-brand attractiveness, advertising attitudes, brand association, private-brand loyalty, and repurchase intention. The study found private-brand avatar consistency and private-brand attractiveness directly influence advertising attitudes and brand association, advertising attitudes, and brand association positively affect private-brand loyalty, and private-brand loyalty significantly and positively affects repurchase intention. It is particularly important for a corporation that wants to create a private-brand avatar, to consider the extent of consistency and attractiveness of private-brand avatar.
\end{abstract}

Keywords: Private-brand avatar consistency, Private-brand avatar attractiveness, Advertising attitude, Brand association, Private-brand loyalty, Repurchase intention

\section{INTRODUCTION}

Fan economic theory is defined as the emotional capital between brand and Fan, which enhances and connects the emotion between fans and the brand by using a fan community[1]. The fan economic theory has a few essential elements. First, the channel connected with fans. For example, the brand often interacts with fans via conferences, advertising, concert, welfare activities, and so on. Secondly, the association between brand logo and brand, i.e., brand logo characteristic image must connect with the brand, when watching the brand logo, the consumer can easily associate the brand logo with the brand, including brand color, image and more, also have a positive emotion on brand or even have better purchase intention and repurchase intention. That will maximize the benefits of the brand[2].

In order to establish a good connection with consumers, companies often establish good interactions with fans through celebrity endorsers and avatars. Although celebrity endorsers can create a high turnover for businesses, if their scandals or embarrassment are reported by media, they will reduce the company's reputation and image. Furthermore, although avatars can avoid the image crisis of celebrity endorsers, i.e., Hello Kitty, Winnie the Pooh, which is not only limited by limitation authorization fee and years. but also, it is difficult for consumers to connect emotionally with the endorsed brand. To resolve this issue, many companies have created their private-brand avatars based on their corporate culture. such as McDonald's, Kentucky Fried Chickens.

As such, this research explores the effectiveness of the private-brand avatar base on the previous research on Fan economic theory. Avatars were divided into consistency, attractiveness, expertise, trustworthiness in the previous study [3], since an avatar does not have education as experts do and without knowledge background. Thus, this study measures the avatar by focusing on private-brand avatar attractiveness and private-brand avatar consistency. After interviewing experts and scholars, it appears Fan economic theory usually measures the effectiveness of avatars based on advertising attitude and brand association. Also, private-brand brand loyalty and repurchase intention are used to detected marketing effectiveness after absorbing industry marketing 
experience. Due to there remains a lack of practical research on the use of a private-brand avatar in the retailing business mode[4]. To fill this research gap and explore the effect of the private-brand avatar on retail business. Therefore, this study proposes six novelty constructs, namely, private-brand avatar attractiveness, private-brand avatar consistency, advertising attitude, brand association, private-brand brand loyalty, and repurchase intention as a research framework and discusses its theoretical and managerial implications.

\section{THEORY AND HYPOTHESES}

\subsection{The positive effects of Private-brand avatar consistency $(P B C)$ and Private-brand avatar attractiveness (PBA) on advertising attitude}

\section{$(A A)$}

In the avatar literature, consistency generally refers to the degree of similarity or consistency between the avatar and the brand (or product category)[5]. Applying that definition, this study proposes a private-brand avatar consistency defined as the process whereby the consumer perceives the associative link between the private-brand product attributes and the avatar[6]. Schema theory posits that if avatar schemas match product schemas, then the avatar will become an information source of adaptive significance on which people then rely [7].

Advertising is an important resource of consumer emotional response and positive evaluation [8]. In addition, advertising attitude is identified as the consumer's overall feeling toward that advertising [9], particularly when viewed as a powerful explanatory construct used in advertising theory to measure ad effectiveness [10]. A literature review suggests that if the avatar and brand image are consistent, the consumer will develop a positive attitude [11]. Applying the Match-up hypothesis, the consistency between an avatar and its endorsed brand will positively influence the advertising effect [12], and lead the consumer toward positive advertising attitude[13]. Thus, private-brand avatar consistency is a crucial antecedent of consumers' attitudes and behavioural intention toward advertising. Accordingly, the following hypothesis is posited here:

H1: Private-brand avatar consistency has a positive influence on advertising attitude

The attractiveness comes from credibility, which illustrates how much the avatar's physical attraction, familiarity, and political status is perceived by the consumers [14] Recently, the avatar has become more popular and an effective way to increase advertising effect[15]. Therefore, avatar attractiveness and expertise are the key factors to measure advertising effectiveness. As the avatar doesn't have the same experience (educational background and clinical experience) as expertise, this study measures its advertising effectiveness based on the attractiveness item.

Several researchers have proven that an attractive avatar can improve advertising effectiveness and lead the consumer to have a positive advertising attitude [16]. A private-brand avatar contains the attractiveness of an endorser, and also contains certain cultural elements of the endorsed brand. Thus, the consumer obtains information from a private-brand avatar more easily than from a virtual avatar when watching an advertisement. In General, a private-brand avatar can make up for the common defects of avatars. Therefore, this study argues that private-brand avatar attractiveness positively influences advertising attitude and offers the following hypothesis:

$\mathrm{H}$ 2: Private-brand avatar attractiveness has a positive effect on advertising attitude

\subsection{The positive effects of Private-brand avatar consistency $(P B C)$ and Private-brand avatar attractiveness (PBA) on brand association (BA)}

Brand associations are the central aspect of brand equity, referring to a consumer's purchase experience and a preference linked to the memory of a brand. Previous studies have confirmed that the effectiveness of an avatar on a corporation derives from the consistency between the avatar and the endorsed brand [17]. When that degree of consistency is high, consumers are familiar with the brand because of the avatar and have a positive attitude toward it. That consistency will produce a positive effect on brand association and endorsement effect [18]. Recently, scholars have proposed that the significant effect of consistency on brand association comes from the alliance between the avatar and its brand [17]. Moreover, private-brand avatar is designed from the corporate culture and image, so its character and personality are consistent with the corporate brand and its spirit. If consistency is high, it will increase the positive consumer attitude toward brand association. Accordingly, the following hypothesis is posited:

H3: Private-brand avatar consistency has a positive effect on brand association

Scholars suggest that brand associations help consumers obtain information and create positive brand recall, which in turn guides consumers to make a purchase decision and let the corporation extend its brand and set up and differentiate its marketing position [19]. Scholars also argue that an attractive avatar has a positive effect on consumer brand evaluation [17]. An attractive avatar will be more effective than an unattractive avatar for consumer brand recall and purchase intention [13], and also have a positive impact on brand equity [5] When private-brand avatar created by the corporation, its image and character are consistent with that of the corporation. Thus, private- 
brand avatar attractiveness increases the effect of brand associations. Thus, this study proposes the following:

H4: Private-brand avatar attractiveness has a positive effect on brand association

\subsection{The positive effects of Advertising attitude $(A A)$ and Brand association (BA) on Private- brand loyalty $(P B L)$}

Scholars define brand loyalty as the past degree of pre-dispositional commitment toward a brand [20]. Recently, several studies have argued that brand loyalty is "the degree to which the buyer has repeatedly purchased a particular brand during recent years"[21]. If the evaluation of advertising is high, then consumers will find purchasing the products is more enjoyable and valuable[22]. In turn, this advertising will create a positive attitude and movement toward brand loyalty and evaluation of the corporation. Recently, more and more scholars have confirmed that advertising directly influences brand loyalty, particularly in a competitive atmosphere, where stronger brand loyalty requires more positive advertising [23]. Accordingly, the following hypothesis is posited:

H5: Advertising attitude has a positive effect on private-brand loyalty

Ha et al. [19] pointed out that brand loyalty is the psychological result of consumer behavior and consumer attitudes toward a particular brand. After measuring brand loyalty for 27 different corporations, [24] learned that the degree of brand loyalty highly relates to brand attitude, and indeed, [25]believed that brand loyalty is influenced by brand attitude. When consumers become familiar with a brand, they naturally have a strong, stable, positive brand association, which leads to a specific brand reaction, i.e., commitment, trust, loyalty, purchase intention and recommendation, etc.[26]. Thus, brand association is the basic element of brand loyalty [27]. Therefore, this research suggests the following hypothesis:

H6: Brand association has a positive effect on privatebrand loyalty

\subsection{The positive effects of Private-brand loyalty $(P B L)$ on repurchase intention $(R I)$}

Intention is a signal of an individual willingness to continue performing a particular behavior and is background that affects behavior directly [28]. Based on certain subjective criteria, scholars define repurchase intention as consumers' continuing to buy a product or service when they find it useful [16]. Few studies have examined the significant effect of brand loyalty on repurchase intention. In private-brand economic theory, brand loyalty is critical for increasing emotional equity. When consumers are influenced by a private-brand avatar's consistency and attractiveness, they will have a positive attitude toward brand loyalty and brand attachment, which increases their consumer repurchase intention.

The notion of repurchase intention has gained increasing attention in different settings, including elearning [29]; mobile commerce[30]; online communities ; and self- service technologies[31]. Few studies have focused on offline retailing. Accordingly, this study explores that relationship. Previous scholars have pointed out that brand loyalty encourages repurchase intention[10], even maintaining it [32]. When the relationship between consumers and a corporation becomes closer, emotional commitment increases [32]. Thus, the following hypothesis is proposed:

H7: Private-brand loyalty has a positive influence on repurchase intention

\section{RESEARCH METHODOLOGY}

\subsection{The Measures}

This study adopted its measurement items from previous studies, and all scales included multiple items. All the latent constructs and measured items were measured using a 5-point Likert scale ranging from 1 (strongly disagree) to 5 (strongly agree). The research modified three items from [5] to measure PBC. Three questions were developed to access PBA applying [15]; three questions from the study by Lee[8] were designed to measure AA; three questions from $\mathrm{Ha}[19]$ were designed to measure BA. Based on Kim[22], three questions were used to access PBL. The three items from [28] were adapted to measure RI.

\subsection{Data Collection and the Sample}

This research selects the private-brand avatar "OPEN CHAN" launched by Taiwan 7- ELEVEN in 2005 as the research subject. Due to "OPEN CHAN" often interacts with fans via holding an autograph session, advertising, concert, welfare activities and so on. Moreover, "OPEN CHAN"s' characteristic image connect with 7-ELEVEN, when watch the "OPEN CHAN", consumer can easily associate "OPEN CHAN" with 7-ELEVEN, including brand color, image and more, also have a positive emotion on 7-ELEVEN.It has helped 7-ELEVEN produce annual profits about nearly 1 billion NTD per year (33.3 million USD), and sustainable development [29]. Therefore, this study selects consumers from Taiwan 7-ELEVEN as the survey object, based on fan economy to find out how the private-brand avatar can cause the loyalty of customers and repurchase intention.

The study referred to previous studies to design the questionnaire items. In the first pre-test, six experts and scholars were asked to revise the questionnaire. In the 
second pre-test, the questionnaire was randomly distributed to 37 consumers who purchased goods from 7-ELEVEN; they were asked to write out a questionnaire and determine the meaning of terminology and questions. Therefore, the questionnaire in this study has high content validity. After the second pre-test, the sample is randomly selected consumers in Taipei 7-ELEVEN stores. In order to improve the effective survey response rate, the research team convened each randomly selected consumer to explain the research goals and the contents of the questionnaire face to face. The validity of high content is a necessary condition for the questionnaire survey in this study.

This study conducted its survey from June to July 2020 for one month. Questionnaires were randomly mailed to 600 Taiwanese consumers who had purchased 7-ELEVEN products. A total of 530 valid questionnaires were recovered at a valid questionnaire response rate of $88.3 \%$, which was higher than the minimum sample size of 345 and considered acceptable for this study [34]. The descriptive statistics of the questionnaire sample: males totaled 215 (40.6\%) and females, 315 (59.4\%). Most respondents were between 40 and $49(23.0 \%)$ and graduated from college or university $(42.3 \%) ; 35.3 \%$ indicated their monthly disposable income was between US\$ 1,000 to US\$ 1,700 .

\section{EMPIRICAL RESULTS}

\subsection{Convergent and discriminant validity and the results of the measurement model}

A confirmatory factor analysis confirmed the factor loadings of the six study constructs and assessed the model fit (see Table 1). Cronbach's alpha internal consistency reliability coefficients were calculated and ranged from 0.725 to 0.840 for the six constructs, above the common threshold value of 0.70 suggested by Nunnall[35] The average variance extracted (AVE) value for all constructs ranged from 0.51 to 0.65 , most indeed exceeding the suggested value of 0.5 for discriminant validity.

Table 1. Reliability and Validity of the Constructs

\begin{tabular}{|c|c|c|c|c|c|c|}
\hline $\begin{array}{c}\text { Factor } \\
\text { Cronbach's } \alpha\end{array}$ & \multicolumn{2}{|c|}{$\begin{array}{l}\text { Items/ Standardized } \\
\text { Factor Loadings }\end{array}$} & AVE & CR & Mean & SD \\
\hline \multirow{3}{*}{$\begin{array}{c}\text { PBC } \\
\alpha=0.84\end{array}$} & PBC1 & 0.78 & \multirow{3}{*}{0.64} & \multirow{3}{*}{0.84} & 3.82 & 0.749 \\
\hline & $\mathrm{PBC} 2$ & 0.82 & & & 3.72 & 0.869 \\
\hline & PBC3 & 0.80 & & & 3.67 & 0.888 \\
\hline \multirow{3}{*}{$\begin{array}{c}\text { PBA } \\
\alpha=0.838\end{array}$} & PBA1 & 0.85 & \multirow{3}{*}{0.65} & \multirow{3}{*}{0.85} & 3.96 & 0.926 \\
\hline & PBA2 & 0.88 & & & 3.87 & 0.896 \\
\hline & РВA3 & 0.67 & & & 3.88 & 0.879 \\
\hline \multirow{3}{*}{$\begin{array}{c}\text { AA } \\
\alpha=0.725\end{array}$} & AA1 & 0.71 & \multirow{3}{*}{0.57} & \multirow{3}{*}{0.73} & 4.04 & 0.738 \\
\hline & AA2 & 0.62 & & & 3.56 & 0.851 \\
\hline & AA3 & 0.72 & & & 3.52 & 0.846 \\
\hline \multirow{2}{*}{$\begin{array}{c}\text { BA } \\
\alpha=0.735\end{array}$} & BA1 & 0.67 & \multirow{2}{*}{0.52} & \multirow{2}{*}{0.75} & 3.73 & 0.784 \\
\hline & BA2 & 0.63 & & & 3.72 & 0.788 \\
\hline
\end{tabular}

\begin{tabular}{|c|c|c|c|c|c|c|}
\hline & BA3 & 0.80 & & & 3.33 & 0.899 \\
\hline \multirow{3}{*}{$\begin{array}{c}\text { PBL } \\
\alpha=0.773\end{array}$} & PBL1 & 0.66 & \multirow{3}{*}{0.51} & \multirow{3}{*}{0.75} & 3.31 & 0.973 \\
\hline & PBL2 & 0.76 & & & 3.67 & 0.898 \\
\hline & PBL3 & 0.71 & & & 3.31 & 0.896 \\
\hline \multirow{3}{*}{$\begin{array}{c}\mathrm{RI} \\
\alpha=0.783\end{array}$} & Rl1 & 0.76 & \multirow{3}{*}{0.55} & \multirow{3}{*}{0.79} & 3.33 & 0.899 \\
\hline & $\mathrm{R} 12$ & 0.76 & & & 2.54 & 0.966 \\
\hline & RI3 & 0.71 & & & 3.52 & 0.964 \\
\hline
\end{tabular}

Table 2. Descriptive Statistics and Correlation of Study Variables

\begin{tabular}{|c|c|c|c|c|c|c|c|c|}
\hline Constructs & $\mathrm{M}$ & $\mathrm{SD}$ & 1 & 2 & 3 & 4 & 5 & 6 \\
\hline PBC & 3.76 & 0.71 & $(0.64)$ & & & & & \\
\hline PBA & 4.01 & 0.73 & 0.245 & $(0.65)$ & & & & \\
\hline AA & 3.89 & 0.63 & 0.260 & 0.436 & $(0.47)$ & & & \\
\hline BA & 3.70 & 0.72 & 0.289 & 0.198 & 0.296 & $(0.50)$ & & \\
\hline PBL & 3.42 & 0.73 & 0.136 & 0.124 & 0.193 & 0.262 & $(0.51)$ & \\
\hline RI & 2.86 & 0.80 & 0.147 & 0.192 & 0.202 & 0.236 & 0.358 & $(0.55)$ \\
\hline
\end{tabular}

The construct reliability (CR) estimates varied from 0.73 to 0.85 , thereby exceeding the acceptable cutoff value of 0.60 suggested by Anderson[36]. The above analysis represents that the measurement model had excellent convergent validity (see Table 2). The CFA model was considered appropriate to conform to the standards suggested by Kline[37]. Besides, the $\chi 2 / \mathrm{df}$ ratio of less than 3.0 was used as the common decision rule of an appropriate model fit. Other indicators of goodness of fit as recommended by Kline (1998) (RMSEA=0.059, $\mathrm{CFI}=0.97, \quad \mathrm{IFI}=0.96, \quad \mathrm{NFI}=0.97$ ) indicate that the hypothesized model evident the well of empirical data.

\subsection{Results of the Measurement Model}

This study running the SEM to examines the model as relationships between PBC, PBA, AA, BA, and PBL as well as RI. The result of the analysis is as follow: the RMSEA 0.050, under the cutoff point of 0.08 , the chisquare/degrees of freedom $\left(\chi^{2} / \mathrm{df}\right)$ ratio of 2.305 , which is less than 3 , the CFI is 0.968 , and NFI is 0.944 , both of which are over of 0.90 [38]. Therefore, the measurement model showed a satisfactory goodness-of-fit index. All six hypotheses are supported (Table 3).

Table 3. Test Results for the Hypotheses

\begin{tabular}{|l|l|c|c|}
\hline Hypothesized path & Standardized estimate & t-value & $\begin{array}{c}\text { Hypothesis } \\
\text { supported }\end{array}$ \\
\hline $\mathrm{H} 1: \mathrm{PBC} \rightarrow \mathrm{AA}$ & $0.27^{\star \star \star}$ & 5.20 & YES \\
\hline $\mathrm{H} 2: \mathrm{PBC} \rightarrow \mathrm{BA}$ & $0.51^{\star \star *}$ & 8.01 & YES \\
\hline $\mathrm{H} 3: \mathrm{PBA} \rightarrow \mathrm{AA}$ & $0.68^{\star \star *}$ & 11.50 & YES \\
\hline $\mathrm{H} 4: \mathrm{PBA} \rightarrow \mathrm{BA}$ & $0.26^{\star \star *}$ & 4.45 & YES \\
\hline $\mathrm{H} 5: \mathrm{AA} \rightarrow \mathrm{PBL}$ & $0.29^{\star \star *}$ & 4.65 & YES \\
\hline $\mathrm{H} 6: \mathrm{BA} \rightarrow \mathrm{PBL}$ & $0.51^{\star \star *}$ & 7.31 & YES \\
\hline $\mathrm{H} 7: \mathrm{PBL} \rightarrow \mathrm{RI}$ & $0.82^{\star \star *}$ & 12.24 & YES \\
\hline
\end{tabular}




\section{CONCLUSION}

\subsection{Theoretical implications}

Based on the fan economy, the company's use of private brand avatars has become a key factor in 7ELEVEN's success in Taiwan. When consumers associate private brand avatars with a brand, it helps to differentiate its business model and increase market share. For example, 7-ELEVEN not only effectively combines "OPEN CHAN" with 7-ELEVEN's products and brands, but also maintains close contact with consumers through fan meetings, concerts and other events, and expands its own brand. The peripheral products of the avatar have effectively increased operating profits. It is convenient for consumers to distinguish the difference between 7-ELEVEN stores and other convenience stores. It is recommended that when the administrator creates a private brand avatar, First, the corporation should know their competition situation, the features of their brand and products, and development goal. For example, utilizing its business spirit of "always open in 7-ELEVEN", and named it "OPEN CHAN". Literally, that means no matter what difficulty occurs, 7ELEVEN would accompany you. Secondly, its image should be attractive and consistent with the corporation spirit. When a consumer reads this avatar story, it is easy for them to associate 7-ELEVEN with "OPEN CHAN" because its image consistent with 7-ELEVEN. The corporation should focus on packing and advertising it is private-brand avatar, moreover considering how to establish its long-term image effect. Considering the long-term benefit of corporate brand and product promotion, it is useful to strengthen the avatar image in different media, i.e., comic story, cartoon, and fans community.

\subsection{Limitations and future of the Study}

This study has the following limitations: The first limitation is related to the recapitulation of the results. Since the research has been carried out specifically for 7ELEVEN consumers, therefore the effort cannot be extended except for the present sampling frame. Secondly, the selection of 7-ELEVEN consumers in Taiwan has also resulted in another limitation of a comparatively smaller sample size. Third, geographical confinement and scarcity of time also were limitations of the research. Though the model's capability to forecast customer loyalty and repurchase intention is notable, other factors may be added to enhance the predictive power of the proposed model. Finally, the research is focused on convenience store, the results may differ by industry.

\section{REFERENCES}

[1] Z. Fraade-Blanar, A. M. Glazer, Superfandom: How Our Obsessions are Changing What We Buy and Who We Are. 2017. WW Norton \& Company.

[2] C. Min, Entrepreneurs talk about the post-market: 711 achieved the great benefit. http:// www.auto a.hc360.com.

[3] M.T. Liu, Y. Huang, M. Jiang. Relations among attractiveness of endorsers, match-up, and purchase intention in sport marketing in China. Journal of Consumer Marketing, 2007, pp.358-365.

[4] G. L. Pinto, C. Dell'Era, R. Verganti, E. Bellini, Innovation strategies in retail services: solutions, experiences and meanings. European Journal of Innovation Management. 2017, pp.190-209.

[5] N. Fleck, M. Korchia, I. LeRoy. Celebrities in Advertising: Looking for Congruence or Likability? Journal of Psychology \& Marketing, 2012, pp.651662. DOI: 10.1002/mar.20551

[6] A. Dwivedi, L.W. Johnson, R. McDonald. Celebrity endorsements, self-brand connection and relationship quality. International Journal of Advertising, 2015, pp.486-503.

[7] J. Knoll, J. Matthes. The effectiveness of celebrity endorsements: a meta-analysis. Journal of the Academy of Marketing Science, 2017, 45(1), pp.5575.

[8] S.S. Hyun, W. Kim, M.J. Lee. The impact of advertising on patrons' emotional responses, perceived value, and behavioral intentions in the chain restaurant industry: The moderating role of advertising-induced arousal. International Journal of Hospitality Management, 2011, 30(3), pp.689-700. DOI:10.1016/j.ijhm.2010.10.008

[9] A. Shaouf, K. Lü, X. Li. The effect of web advertising visual design on online purchase intention: An examination across gender. Computers in Human Behavior, 2016, pp. 622-634. DOI:10.1016/j.chb.2016.02.090

[10] S.B. Mackenzie, R.J. Lutz, G.E. Belch. The role of attitude toward the ad as a mediator of advertising effectiveness: A test of competing explanations. Journal of Marketing Research, 1986, pp:130-143. DOI: $10.2307 / 3151660$

[11] S.K. Koerning, A.L. Page. What if your dentist looked like Tom Cruise? Applying the match-up hypothesis to a service encounter. Psychology \& Marketing, 2002, 19(1), pp.91-110.

[12] S. Ahn, H. Kim, J.A. Forney. Fashion collaboration or collision? Examining the match-up effect in co- 
marketing alliances, Journal of Fashion Marketing and Management, 2010, pp.6-20.

[13] D. Yoon, Y.K. Kim. Effects of Self-Congruity and Source Credibility on Consumer Responses to Coffeehouse Advertising. Journal of Hospitality Marketing \& Management, 2015, pp.167-196. DOI:10.1080/19368623.2014.1001932

[14] W.J. McGuire, Attitudes and attitude change. The handbook of social psychology, 1985, pp.233-346. DOI:10.1146/annurev.psych.121208.131609

[15] M.T. Liu, Tingchi, M, J.L. Brock. Selecting a female athlete endorser in China. European Journal of Marketing, 2010, pp. 1214-1235. DOI:10.1108/03090561111137688

[16] Q. Thi, P.L. Van. Consumers' Perception towards Corporate Social Responsibility and Repurchase Intention: A Study of Consumer Industry in Vietnam Journal of Industrial Engineering \& Management Systems, 2016, pp.173-180. DOI: $10.1108 / 03090561111137688$

[17] L. Bergkvist, K.Q. Zhou. Celebrity endorsements: a literature review and research agenda. International Journal of Advertising, 2016, pp.642-663.

[18] J. Ilicic, C.M. Webster. Celebrity co-branding partners as irrelevant brand information in advertisements. Journal of Business Research, 2013, pp.941-947.DOI

10.1016/j.jbusres.2011.12.014

[19] H.Y. Ha, S. Janda, S. Muthaly. Development of brand equity: evaluation of four alternative models. The Service Industries Journal, 2010, pp.911-928. DOI: $10.1080 / 02642060802320253$

[20] G.J. Longwell. Managing brand equity: Capitalizing on the value of a brand name: David A. Aaker, The Free Press, New York (1991). Journal of Business Research, 1994, 247-248.

[21] K.S. Ong, B.N. guyen, S.F. SyedAlwi. Consumerbased virtual brand personality (CBVBP), customer satisfaction and brand loyalty in the online banking industry. International Journal of Bank Marketing, 2017, pp.370-390.

[22] S. Kim, I. Kim, S.S. Hyun. First-class in-flight services and advertising effectiveness: antecedents of customer-centric innovativeness and brand loyalty in the United States (US) airline industry. Journal of Travel \& Tourism Marketing, 2015, 33(1), pp.118-140.

[23] S. Dolnicar, K. Grabler, B. Grün, A. Kulnig. Key drivers of airline loyalty. Tourism Management,
2011, 32(5), pp.1020-1026. DOI :

10.1016/j.tourman.2010.08.014

[24] T. Abimbola, M. Trueman, O. Iglesias, F. Liu, J. Li, D. Mizerski, H. Soh, Self-congruity, brand attitude, and brand loyalty: a study on luxury brands. European Journal of Marketing. 2012.

[25] O. Koll, S. Von Wallpach, intended brand associations: Do they really drive consumer response? Journal of Business Research,2014, 67(7). pp.1501-1507. DOI : 10.1007/s11747-0160503-8

[26] A. Ferrand, L. Robinson, P. Valette-Florence. The intention-to-Repurchase Paradox: A Case of the Health and Fitness Industry. Journal of Sport Management, 2010, 24(1), pp.83-105.

[27] I. Ajzen. Perceived behavioral control, self-efficacy, locus of control, and the theory of planned behavior. Journal of applied social psychology, 2002, 32(4), pp.665-683.

[28] Y. Zhang, Y. Fang, K.K. Wei, Z. Wang. Promoting the intention of students to continue their participation in e-learning systems. Information Technology \& People. 2012, pp.356375.DOI:10.1108/09593841211278776

[29] L. Gao, K.A. Waechter, X. Bai. Understanding consumers' continuance intention towards mobile purchase: A theoretical framework and empirical study-A case of China. Computers in Human Behavior, 2015, 53, pp.249-262. DOI:10.1016/j.chb.2015.07.014

[30] S.W. Chou, H.T. Min, Y.C. Chang, C.T. Lin. Understanding continuance intention of knowledge creation using extended expectation-confirmation theory: an empirical study of Taiwan and China online communities. Behaviour \& Information Technology, 2010, pp.557-570. DOI:10.1080/01449290903401986

[31] W. Chiu, D. Won. Consumer-brand relationships in sports products and repurchase intention. International Journal of Sports Marketing and Sponsorship, 2016, pp.243-259. DOI:10.1108/IJSMS-08-2016-013

[32] Y. Shin, V.V. Thai, D. Grewal, Y. Kim. Do corporate sustainable management activities improve customer satisfaction, word of mouth intention and repurchase intention? Empirical evidence from the shipping industry. The International Journal of Logistics Management, 2017, pp.555-570. DOI:10.1108/IJLM-11-20150220 
[33] J.F. Hair, R.E. Anderson, B.J. Babin, W.C. Black. Multivariate data analysis: A global perspective, 7th ed., Pearson Education, NJ: Upper Saddle River, 2010.

[34] J.C. Nunnally, Psychometric Theory, 2nd ed., NY: McGraw-Hill, 1978

[35] J.C. Anderson, D.W. Gerbing. Structural equation modeling in practice: a review and recommended two-step approach, Psychological Bulletin, 1988, 103(3), pp.411-423. DOI:10.1037//00332909.103.3.411

[36] R.B. Kline, Principles and practice of structural equation modeling, NY: Guilford Press, 1998.

[37] L.T. Hu, P.M. Bentler, Cutoff criteria for fit indexes in covariance structure analysis: Conventional criteria versus new alternatives, Structural equation modeling: a multidisciplinary Journal,1999, 6(1), pp.1-55. 